\title{
The Discursive Metonymy in the Imagery of American Folklore Ballads
}

\section{Дискурсивна метонімія в образності американських фольклорних балад}

\author{
Tetiana Suvorova \\ Ph.D. in Linguistics, \\ Assistant Professor
}

\author{
Тетяна Суворова \\ кандидат філологічних наук, \\ доцент
}

\author{
E-mail: 08142328.ss@gmail.com \\ https://orcid.org/0000-0002-0209-6785 \\ ResearcherID: S-3754-2017
}

Kherson State University, Department

of the English Language and the Methods of its Teaching

$\triangle 2$, Universitetska Str., Kherson,

Ukraine, 73000
Херсонський державний університет, кафедра англійської мови та методики ії викладання $\checkmark$ вул. Університетська, 2, Херсон, Україна, 73000

Original manuscript received November 01, 2018

Revised manuscript accepted March 29, 2020

\begin{abstract}
Introduction. The article presents the effort to describe the semantics of American folklore ballads with account of the links between the images involved in the text creation. The discursive metonymy is considered to be the connecting cognitive mechanism of the ballad concepts that are objectified by the verbal images in the texts. Via the cognitive mechanism of the discursive metonymy the creative activity delivers understanding each text of the ballads as the unity of images presenting the definite creative idea.

Materials and Methods. American Folklore ballads serve to be the material of the scientific analysis, as the texts represent the collective typical and recursive artistic categorizing and conceptualizing of the reality. Thus, the phenomenon of the discursive metonymy can be proved to be a typical means of the textual images organization. The theory of the conceptual metaphor and the conceptual tropes facilitate the
\end{abstract}


analysis of the semantics of the ballad texts. The theory of basic concepts in general and the integrated model of the networks between the concepts lie in distinguishing the dominant models of the discursive metonymy.

Results. The typical linguistic means are involved in the ballad texts to enable the correlation of the ballad images within the model of the discursive metonymy. These are the repetitions in all the levels: phonological, lexical, syntactical resulting in the formation of the concept networks via the discursive metonymy in the textual level. The anaphora and cataphora, the ellipsis, and the conjunctions of different types are progressed in the development of the textual unity via the mechanism of the discursive metonymy.

Conclusions. The discursive metonymy plays the structuring and generalizing role in the system of the images in the ballad texts.

Key words: a ballad, an image, the discursive metonymy, the cognitive mechanism, the system of images.

\section{Introduction}

The structure of ballad imagery as a synergetic system contains information about the structures of separate verbal images as well as points to the interaction of the cognitive structures of each verbal image one with another within the structure of the imagery space. The structure is a model of the imagery system, and therefore it is important to determine the role of each verbal images and its structure in the structure of the whole ballad text. The structure defines the links between the internal content of separate verbal images (cohesion of the text) and manifests itself through cohesion as a structural and grammatical connection, and coherence as semantic-content connectivity, which captures the content of the whole text, forms imagery and text integrity (Lukin, 1993). $\mathrm{K}$. Jung defined the work of art as an individual phenomenon that has an anonymous power; it dictates the artist how to fix the images (Yung, 1992). That is, the unconscious via archetypes demonstrates succeeding historical heritage of human knowledge. The collective unconsciousness is just an opportunity which people inherited from ancient times in the form of mnemonic images. These representations are innate possibilities of reality representation (ibid.: 117). Consequently, the peculiarity of the imagery structure formation in the ballad texts is the orientation towards the innate possibilities of thinking and the stages of the artistic consciousness development. 
For cognitive linguists, the comprehension occurs through conceptual mapping across domains (Lakoff \& Johnson, 1980) and language interacts with other mental facilities, such as perception, vision, memory and sensorimotor skills (Cienki, 2005), and not as an autonomous module in our mind (Fodor, 1983).

The idea of «metaphoric competence» was developed as the extension of the cognitive linguistics theories. in the light of the theory of intelligence it is argued by the scholars that «metaphoric intelligence» is affected by the eight types of intelligence, that is visual, verbal, mathematical, kinesthetic, interpersonal, naturalistic, and rhythmic.

Gardner's (1983) paper is to highlight the fact of individual thinking styles that correlate with «literal» thinking styles, or ability to make metaphorical analogies. Nimier states that knowing the metaphorical motivation for the experimental expressions can help the learners of the language to remember the meaning due to salience (Ferreira, 2008). The metaphors are organized and the content is remembered due to the metonymic background of the meaning of the expressions.

Thus, metonymy plays the role of the categorizer of the utterance as a whole due to its associative basis. In terms of the psycholinguistic and neurolinguistic perspective, the metonymy is viewed as the structure of the interface between the linguistic system and the older conceptual system (Piñango, Zhang, Foster-Hanson, Negishi, Lacadie \& Constable, 2017; Ivashina \& Rudenko, 2011; Truhanovskaya, 2009). It is examined as being implemented in speech in systemic highly conventionalized and situational lesser conventionalized cases. In this respect the referential dependency between the named and the intended conceptual entities is labeled as systemic and circumstantial metonymy (Piñango, Zhang, Foster-Hanson, Negishi, Lacadie \& Constable, 2017; Niemeier, 2003). It was suggested by the authors to treat the process of conventionalization as a linguistic categorizer and meanwhile the inducer of a contextual cline (Piñango, Zhang, Foster-Hanson, Negishi, Lacadie \& Constable, 2017). The difference between the two is interpreted as differences in degree, not category.

\section{Methods and technics of the research}

The structural and grammatical links of verbal images is the «installation» of an artistically reconsidered world in ballad texts. 
Modelling the links is possible by establishing rational-logical connections both in the structure of separate verbal images and between structures of verbal images taken as a whole in a ballad text. The imagery of a ballad text is modelled by reconstructing cognitive structures of different degrees of abstraction on the basis of linguistic material involved in the registration of creative ideas. The imagery is determined by a set of features of a content plane, which corresponds to a relatively complete fragment of knowledge (Suvorova, 2015a), and is defined by the boundaries of imaginary space. The ballad imagery space is formed by ways of the selection of means of verbal expression and thematic orientation in accordance with the genre peculiarities of balladry. A set of keywords and fixed phrases, that implement certain cognitive models, determine the range of characteristics of ballad imagery. The cognitive approach to the study of the semantics of the poetic word lies in the analysis of a word, in which there are recorded not only the marks necessary for the identification of the signified but also the naïve knowledge about the signified (Pimenova, 2006). That is why the conceptual schemes are the cognitive tools of imagery.

The conceptualization of knowledge about the surrounding world is based on the archetypal schemes that occur through the establishment of logical connections between the referents and the correlates that form the verbal images. The main types of connections that provide the formation of basic cognitive models can be represented in the form of a scheme (Fig. 1), where the concept A relates to the referent in the structure of verbal images and the concept B with a correlate.

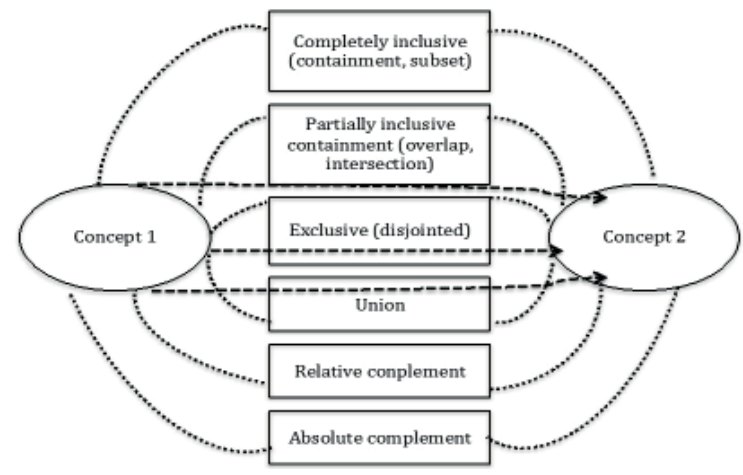

Fig. 1. Model of Possible Logical Connections between Conceptual Domains of Verbal Images 
The semantic-content links between the verbal images define the way the key concepts of the poetic work are drawn to their conceptual sphere as if they were in the pool of gravity. The concepts in the ballad text in their interconnection serve to expand, illuminate or change the semantics of the verbal images involved. Structurally, different types of relationship between the concepts representing the ballad world provide semantic-content links of the verbal image s. R. Bart notes that

"The logic that regulates the text is not based on understanding ...but on metonymy; in the formulation of associations, interconnections, transmissions, the energy output of symbolism is found》 (Bart, 1989: 416).

The cognitive approach to the study of the metonymy can go beyond the traditional understanding the metonymy as a semantic mechanism for the development of the meaning of the word (Truhanovskaya, 2009). In the light of the cognitive paradigm, the metonymy is a cognitive strategy used for logical operations and judgments about the world, conceptualization and categorization of extra-ordinary reality (ibid.: 4). The conceptual metonymy is a fundamental mechanism of knowledge and comprehension of reality; it is applied for the cognitive modelling. Therefore, the metonymy is investigated from the standpoint of the theory of prototypes, conceptual semantics, frame semantics, and other approaches (Turner, 2006; Lakoff \& Johnson, 1980, etc.). If the metonymy is a cognitive mechanism for the representation of knowledge and, as a result, of their reflection in the systemic meanings of linguistic units (Boldyirev, 2000), the conceptual metonymy reflects the systemic values of the verbal images during the creation of a ballad work in relation to the imagery of the folklore ballads. As part of the conceptual structure of imagery, one of the concepts, which create the conceptual dimension, can present another textual concept, associated with it, or the entire imagery structure of the text as a whole. The conceptual metonymy assumes the gestalt character of the perception of a creative work when the whole is perceived through its separate parts and their functions as part of the whole. That is, the relationship between the concepts actuated by the verbal images is produced due to their functioning within the whole, that is, the verbal images and the concepts activated form a system. The conceptual metonymy is especially characteristic of the textual level of knowledge representation 
(Boldyirev, 2000). In the folklore ballad poetry, the poetic world is formed by means of involving the only verbal images that integrate other verbal images, more specific, and enable the activation of interconceptual relationships to provides understanding the text.

\section{Results and Discussion}

Materials. A script with total of 209 items of American folklore ballad texts collected by (Gardner \& Chickering, 2004) was employed for the analysis. The interpretation of the ballad texts was done earlier: the ballad images were analysed and fixed in the tables in the monograph (Suvorova, 2015b). A total of 7572 nominative units correlating with verbal images were taken out o the texts in respect of their text positions (weak and strong) in order to conclude the correlations between predominant ballad concepts and their verbalized realization in definite positions in the text (black - strong position, grey - weaker positions, white - week positions, red - the strongest position in the light of the theory of the Golden Ratio). The method of positional analysis was elaborated by G. Moskalchuk (2003) and K. Belousov (2005). The method is based on the assumption that a creative work is constructed due to the principal of the Golden Ratio. The text from the beginning to the end is taken for the figure 2 .

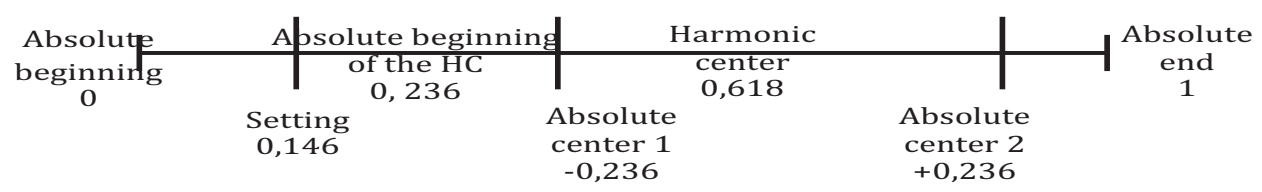

Fig. 2. The strong and weak textual positions within the range 0-1

It gives the possibility to count the strong and weak positions in the text and to check up the positions of the dominant concepts about. It is considered that the proportion of Gold Ratio is one of the strongest positions; it is called a harmonic center of the creative work. The harmonic center (HC) is at the distance 0,618 from the beginning and together with the $\mathrm{HC}$ of the beginning (the distance 0,236) and the end (distance 1) coincide with the certain lexemes realizing dominant concepts in the texts (Fig. 3). The harmonic centers light up the central 
The Discursive Metonymy in the Imagery of American Folklore...

concepts of the ballads, one as leading and the other as the background to the first.
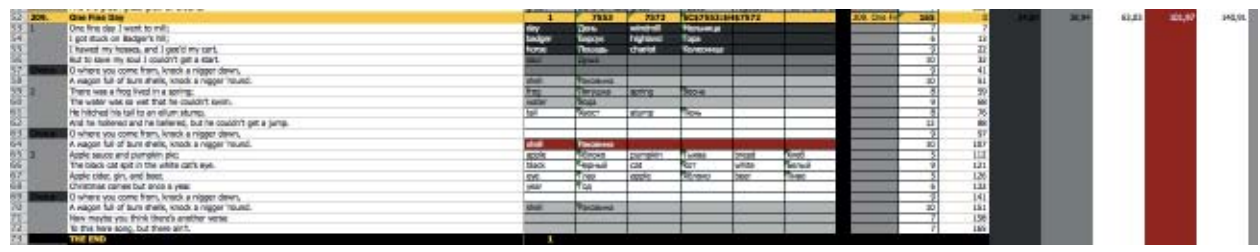

Fig. 3. The ballad text zoning due to the theory of the textual positions with reference to the Golden Radio principals

Each experimental item was fixed in the coloured table, where each colour denotes the text positions due to the theory o the text positions elaborated by Belousov (2005).

One more factor important for the interpretation of the discursive metonymy is taken into consideration: the symbolic images used in the text as they bare the shared cultural knowledge characteristic of the folklore texts and participate in optimization of the verbal presentation of the ballad story by omitting vast usage of words and organizing the images of the ballad story. Main goal throughout the development of the experimental items was coming to the conclusion that the ballad texts employ predominantly symbolic images that are based on the associative type of relations, which is the principal mechanism of the metonymy. Thus, the experimental material taken from the 209 ballad texts shows that amongst 1259 symbolic items fixed in the dictionaries of symbols 893 items are found in the experimental texts (Fig. 4). In the sample taken from the table of the analysed items the links of the three on-line dictionaries are given to each symbolic item with the meanings of them, as well as the notice in which ballad the symbol can be found.

Within the creative work a verbal image is connected with other images forming typical chains that structure a conceptual space of the ballad world. The cognitive basis of the process of the ballad interpretation is limited to a set of propositions that serve to be universal cognitive tools to connect textual concepts. The propositions belong to five highly abstract basic frames that are the basis for the isomorphism of different conceptual ties. S. Zhabotynska (2010) defines five basic frames. These are: 
The Thing Frame (SOMEBODY/ SBD/ or SOMETHING / STH), the Action Frame (SBD/STH (the doer) acts/makes), the Possessive Frame (the possessor/the possessed has), the Identification Frame (SBD/STH-identified is SBD/STH-identifier), and the Comparative Frame (SBD/STH-compared is (as) SBD/STH-correlate).

The interpretation of the text ends in final understanding the ballad through the concept or concepts that generalize the whole ballad story and associates with all other concepts of the text. The discursive metonymy is sustained by a limited number of propositions. Each experimental item has two parts: a context (interpreted via fixed propositions), the metonymy or matched literal control.

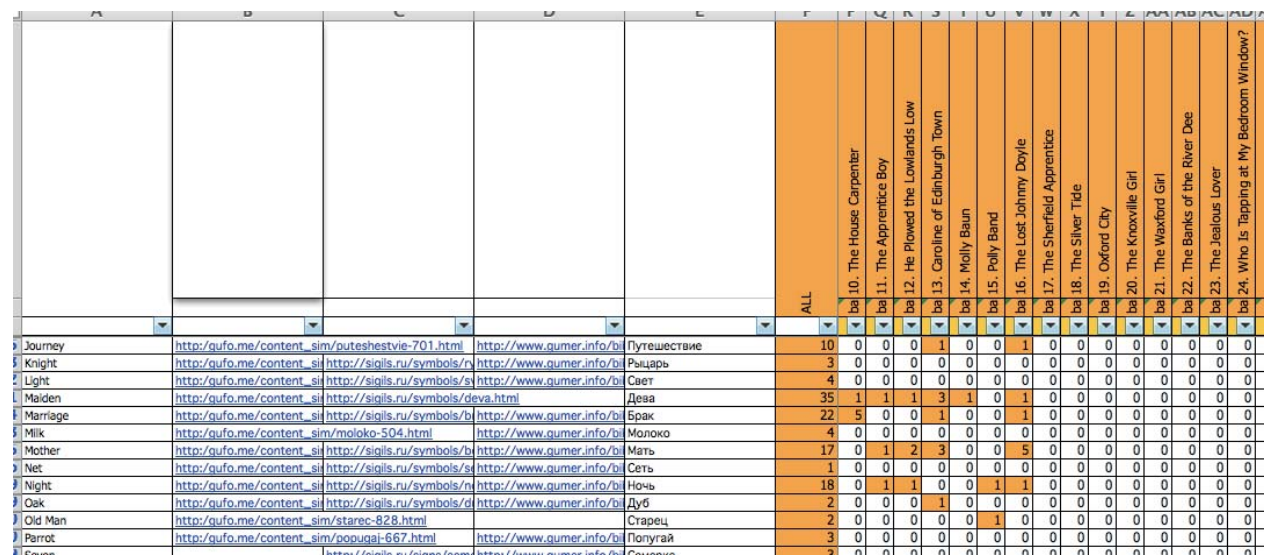

Fig. 4. The symbols from the ballad texts with links to the cites where they are interpreted

The metonymic propositions were normed in a separate list and supplied with the examples.

On the basis of the norming results, the 25 high-rated propositions of each metonymy type were collected.

The list of the metonymic propositions is provided by examples below.

The study of imagery as a system determines the perspective of investigation of the links and relationships between the concepts of the verbal images in the ballad text. The textual level of the imagery study allows to reveal the mechanisms of the conceptualization of the extraspoken situation through the systems properties of the verbal images within the ballad text. The mechanism found in the folklore ballad texts 
is the discursive metonymy, which is used for the purpose of generalized representation of the facts of the ballad reality (Suvorova, 2014). The discursive metonymy is an interface of the semantic-content links of the verbal images and the organization of the verbal images into a system since it performs the generalizing function in creative thinking at the systems level. Such a mechanism of the imagery organization, as the discursive metonymy, involves a metonymic shift of attention due to the cognitive means of association; the focus of attention remains unchanged in the conceptual structure of the imagery. The discursive metonymy acts as a mechanism of the synergetic organization of the structural components of the imagery as it allows to combine the verbal images with a minimal loss of meaning and their maximum concentration. The conceptual metonymy means a certain style of the metonymic image, when one phenomenon is transmitted through another, adjacent, the one that causes an association with a holistic phenomenon through its parts and details. In the process of the metonymic shift in the conceptual structures of the imaginary space, some concepts become salient, more distinct, illuminated, since they have the properties that are closest to the prototype, which in its turn allows them to automatically be associated with other conceptual structures that are parts of the whole conceptual space, activated by the imagery of a ballad text.

The metonymic relations of the concepts of the imagery to the expressed conceptual content of the ballad texts determines the possibility of forming the infinite number of meanings (Boldyirev, 2018), which plays a particularly important role in the ballad genre, since the minimum number of the verbal images generates a rich poetic world by means of curtailing information in the structure of each individual verbal image, having strong links with each other. Minimizing information in the structure of the imagery through the conceptual metonymy occurs at the systems level, when the main, most important characteristics of the imagery are activated, it makes it possible to actualize a whole layer of knowledge through one concept, that replaces many in the ballad text.

The conceptual analysis of the authentic material has shown that the metonymic relations can be established between the conceptual structures within the conceptual space of the imagery of American folklore ballads. The metonymic relations between the verbal images may be presented of four main types: spatial, event, syntagmatic and logical. The conceptual metonymy manifests itself at all levels 
of the verbal implementation in the ballads and can be substantive, adjectival, and verbal, that is, it is objectified by the noun, adjective, adverb, and verb.

The discursive metonymy arises in the context of the imagery systems organization as an occasional shift within the actualized poetic world, when one property of the verbal images is transmitted from one phenomenon to another, due to the cognitive procedure of association. As a factor in the structural organization of the imagery, the discursive metonymy is aimed at shifting the emphasis in the system of images, when one verbal image via its concept represents a certain number of other verbal images concepts. In order to successfully interpret the figurativeness, that is actualized by the verbal images in the ballad work, the recipient in the process of inference, that is while reconstructing the ballad world, relies, according to Grais, on the discursive inferences or implications (conversational inferences or implicates) (Gibbs, 1999), which are actualized in the semantics of the nominal units of the verbal images. The discursive inferences arise out of the perception of the system of the verbal images as a holistic entity whose components are conceptually linked and form the hierarchical relationships that arise on the basis of the common ground information. (Gibbs, 1999) for the addressee and the addresser. Thus, the implicates of the verbal images create the context of the ballad work, when they are taken as a system, they actualize the common knowledge and beliefs and emotions for the addressee and the addresser (ibid.: 339), that is, the basis for the associative links between the concepts of the verbal images is the prototype structures that are the long-standing metonymic models (ibid.: 333). These models are formed during the logical comprehension of relations between adjacent verbal images, and therefore determine the logical type of relations between the components of the discursive metonymy. To the list of logical relations that lay in the basis of the discursive metonymy are included the following ones:

- part-to-whole;

- hyper-hyponym (token-to-type);

- causative-consecutive (cause-to-consequence).

Each of the types is the base for variation expansion in other models through the creative reconsidering of the conceptual structure of the imagery. 
Thus, the metonymic relationships of the part-to-whole type are applied in the conceptual space of the folklore ballad works, they are actualized through the activation of the conceptual relations PEOPLE ARE ASSOCIATED WITH PARTS OF THE BODY. It occurs when the conceptual domain HUMAN BODY is actualized by the concepts signifying the parts of the body parts For example, the nominating units - the nouns eye, lip, brow, skin, hair, chin actualize the whole image of the protagonist:

She cast her eyes on little Ned Grove (Lord Valley, \# 57); For her eyes they invite me, but her tongue tells me no (Green Mountain, \# 28); Let the hair of her head be by no means red, I But lovely brown as a berry; / A milk-white skin, and a dimple in her chin, I And her lips as red as a cherry (The Choice of a Wife, \# 78); He kissed her cold lips ten thousand times o'er (Young Diana, \# 165).

In the hyperon-hyponymic relations, the conceptual model GENERAL IS ASSOCIATED WITH CONCRETE is evolved in structuring the conceptual domains of the verbal images, when the concept sphere of the general is actualized through the specific properties of the concrete. For example, the concept sphere HERITAGE is actualized through the specific concepts GOLD, HORSES, MOTHER'S FORTUNE, which are objectified by the nominative units, nouns and numerals:

Go get part of your father's gold / And part of your mother's fee; the horses stood fifty by three (балада Lady Isabel and the Elf Knight, \# 1).

In the ballad Lord Thomas (\# 4) the verbal image The brown girl she has houses and lands; / Fair Ellen she has none, - the concept sphere HERITAGE is realized through the adjacent concept sphere PROPERTY, represented by the concepts HOUSE and EARTH.

The conceptual sphere of family relationships is represented by the concept WORLD TREE in ballads, though in the narrower, specific concept OLD OAK (old oak tree in the text). The nominative units old oak tree, semantically, are the hyponym in relation to the notion tree actualizing the concept WORLD TREE in the ballads \# 1 (Lady Isabel and the Elf Knight), \# 36 (The Old Oak Tree).

The following conceptual models represent the metonymic relationships of the causal-consecutive nature between the structural parts of the verbal images: 
1) FEATURE IS ASSOCIATED WITH TIME WHEN IT IS REALIZED. In the ballad A True Lover of Mine (\# 50) the concept sphere FEELING OF LOVE is represented by the concepts SPRING, AWAKENING OF NATURE, which, in their turn, actualize the possibility to attribute the human properties to natural when the natural phenomena are personified. The cognitive mechanism of the psychological parallelism makes it achievable:

As I went out walking one morning in May, / May ev'ry rose bloom merry in time, / Oh, I met a fair damsel and to her did say, / "I want you to be a true lover of mine.

The discursive inferences appear to be vivid in the process of interpretation of the lines: it's time for spring to awaken nature, to make the plants flourish. The discursive inferences get the recipient guided about the interpretation of the internal state of the protagonist. The character of the ballad is ready to fall in love, which is the consequence of observing the processes in nature.

2) FEATURE IS ASSOCIATED WITH A PLACE OF ITS REALIZATION. In the ballad works, these relationships are actualized in the concept sphere HUMAN FEELING via the concept LOCATION, which causes the associations of the protagonist with pleasant feelings. For example, in the ballad The Lake of Pontchartrain (\# 48) we come across the verbal image: She took me to her father's house where I was treated well. The concept sphere HUMAN FEELING is presented by the concepts of SECURITY, SAFETY, which are actualized through the concept sphere LOCATION represented by the concept FAMILY HOUSE. In the lines, there are causative-consecutive relationships drawn between conceptual domains that structure the verbal image, since we can trace the discursive implicates: good parents treat their children well, they take care of them and protect them, as a result, children are safely kept in the parental house. The concepts of the opposite meaning to the above described are DANGER, THREAT TO LIFE, they actualize concept sphere HUMAN FEELINGS in ballad Lord Lovell (\# 6):

He had not been gone but a year and a day, / Strange countries for to see, / When a languishing thought came into his head / Lady Nancy Belle he'd go see, go see, / Lady Nancy Belle he'd go see.

The discursive inferences that provide the metonymic shift are the conceptual implications, activated by the concept sphere LOCATION 
The Discursive Metonymy in the Imagery of American Folklore...

through the concept of FOREIGN COUNTRY: an unknown place, danger, and potential threat to human life.

3) STATE IS ASSOCIATED WITH CAUSER OF THE STATE. The metonymic shift based on the causative-consecutive relationships can be traced between the adjacent concept spheres in the ballad Barbara Allen (\# 8):

'twas in the springtime / o' the year / When all fair flowers were blooming, / That Squire Grey a-dying lay / For the love of Barbara Allen.

The concept sphere HUMAN FEELINGS is realized through the psychological parallelism, actualizing the concept STATE OF LOVE and the conceptual implicates: spring, the awakening of nature, love in nature denotes love between people. The state of love is associated with the person with who the protagonist is in love, that is, it is associated with the concept sphere CAUSER OF THE STATE.

4) STATE IS ASSOCIATED WITH THE RESULT OF ACTION. The analogical metonymic shift processes are discovered in conceptual domains HUMAN FEELINGS - THE RESULT OF ACTION of the verbal image:

"Where are you from, my blooming youth, / Or are you from the heavens above, or where is your destiny?» (The Merchants Only Son, \# 74).

It is demonstrated through the actualization of the concept of BEING IN LOVE objectified due to the protagonist's attitude towards the heroine of the ballad as a blossoming youth. That is, the concepts FLOURISHING, YOUTH is actualized in the structure of verbal image with the activated conceptual implications: a young girl, beautiful. It proves the attitude of the boy to the girl as a result of his love for her.

The concept sphere HUMAN FEELINGS is represented by the concepts HAPPINESS and JOYFULNESS in the verbal image $O$ Willie, lovely Willie, you're the joy of my heart in the ballad Lovely Willie's Sweetheart (\# 33). It is associated with the concept sphere RESULT OF THE ACTION with the implications: entertainment of the protagonist, making somebody happy, filling somebody's heart with happiness.

In another example from the ballad «Barbara Allen» (\# 8) there is the verbal image 
They grew and they grew to the church spire top / Till they could grow no higher; / And there entwined in a lovers' knot, / The red rose and sweet briar,

that actualises result the concept sphere RESULT OF THE ACTION through the concept PLANTS INTERWEAVED BY A LOVINGLY NODE, it is associated with the related concept sphere STATE OF LOVE.

5) EVENT IS ASSOCIATED WITH STATE. The conceptual metonymy that implements this model is obvious in the structure of the verbal image

She gazed upon this corpse of clay / Till her heart would break of sorrow, / Saying, "My true love died for me today, / I'll die for him tomorrow (Barbara Allen, \# 8).

The conceptual sphere EVENT is activated by the concept PROTAGONIST'S DEATH, it has the associations with the concept sphere HUMAN FEELINGS through the concept GRIEF and the conceptual implicates death of a loved person, a state of sorrow and grief.

The syntagmatic metonymic relations between the conceptual structures of the ballad imagery are manifested in the inter-category shift in the semantics of nominative units that form the verbal image. Two conceptual models manifest the formation of the metonymic relations between the target and source domains in the structure of a verbal image of ballads.

1. The grammatical categories SINGULAR IS ASSOCIATED WITH PLURAL, for example, the word-form eye is used in singular though the meaning is plural in the formation of the verbal image $\mathrm{He}$ kissed her fair cheek; tears stood in the eye (The Rich Merchant's Daughter, \# 38). The same means of economical use of language resources is observed in the following examples of verbal registration of the verbal image:

She watched with a restless,/ And brighter beamed her laughing eye;/ And kissed her marble brow; /When the well-known sound she heard eye

in the ballad Frozen Charlotte (\# 44) - where the nouns are used in singular though expressing the meaning of plurality. 
2. The grammatical transposition of the parts of speech, when one part of speech functions according to the categories of the other. For example, in the ballad The Dark-Eyed Sailor Ball (\# 57), the verbal image is verbalized in the adverb dark-eyed in the following lines 'This my dark-eyed sailor, is my dark-eyed sailor, / That appeased my downfall. It was formed of the phrase to have dark eyes as a result of its reduction to the form of the adverb, by analogy with the formation of impersonal forms of the verb - the adjectival and adverb. The adverb combines the verbal and nominative properties in its grammatical sense, namely verbs and adjective. Therefore, the word-form dark-eyed doesn't express the meaning of belonging to the protagonist, but the fact that such colour of the eyes was inherited from his parents.

Another example of the grammatical metonymic transposition is found in the lines from the ballads: "Dry up those tears, love, for you'll be mine (Two Rigs of Rye, \# 58) and But aye she eyed me auld brakes / As her, an' me sat crackin'-o; (Robin Tamson's Smiddy, \# 67), where the nominative parts of speech the adjective $d r y$ and the noun eye acquire the verbal categories of mood, tense, person, number, aspect, voice, as they are reflected in the use of these categories in the predicative syntactic positions and grammatical forms of words - ending in the examples.

Another interesting example of the grammatical metonymic shift in the meaning of the verbal image is the following: I'll be mistress of my dairy and the milker of my cow (The Dog and the Gun, \# 73) because it reflects a number of the metonymic transformations in the meaning of the noun «milker's». This noun is derived from the verb to milk as the result of the causative-consecutive relationship ACTPRODUCER - ACTION. In its turn, the verb to milk comes from the noun milk, which reflects the causative-consecutive relationships in categorical metonymic shift through the conceptual model ACTION RESULT OF THE ACTION.

The spatial metonymic relations arise when conceptual model LOCATION IS ASSOCIATED WITH EVENT is involved in image formation, that is, mentioning a certain place actualizes certain succession of events in the minds of the lyrical characters of the ballad text. For example, in the verbal image

It was between two rigs of rye / Before the sun had pierced the sky / I heard two lovers talking 
from the ballad Two Rigs of Rye (\# 58). The underlined words denote the place that is associated with the lyrical characters with certain important events from their lives.

The event metonymic relations arise when the key verbal image of a ballad text actualizes the mega-concept of the entire imagery system as integrity. This textual mega-concept causes the work of the whole network of relationships and links between the concepts in a ballad text. The mega-concept is actualized by individual verbal images of a ballad work through the reconstruction of events in the poetic conceptual world. The main mechanism of the event metonymic relationships is the contextual shift when one concept replaces a certain number of text concepts in the mind of the recipient. The following conceptual models of event metonymic relations between verbal images were recorded in the folklore ballads:

\section{POTENTIALITY SUBSTITUTES ACTUALITY.}

For example, in the ballad Kellyburnbraes ballot (\# 155), the implementation of the metonymic contextual shift is based on the model POTENTIALITY SUBSTITUTES ACTUALITY. It is realized through the text concepts that form the alethic modality and draw the meaning of other text concepts into their center. In this way, the value of dominant text concepts expands, that allows them to perform the substitutable function for the scattered text concepts. The result is the formation of the imaginable world as real for the protagonists; the impossible becomes possible in their minds. The ballad tells about a man tired of a scandal wife:

(16) There was an old man in Kellyburnbraes,

Tadal tadal t-alddal dal day;

He married a wife, the plague of his life...

The husband asks the devil to take his wife to the hell and reprimand her for such behaviour. Subsequently, the devil returns his wife to her husband, as she has slain all who were in the hell, for she has become worse than the devil:

(17) Now the devil has got her again on his back,

And he gave her husband, he took her back.

"O here's your auld wife, she has managed well;

She will not get to heaven, and she'll no bide in hell I» 
The ballad world appears to be the vertical three-layer space, where the real world of people occupies the central position, the heaven world is the upper one, and the hell is the lower one. Such geometry of the ballad space drives from the biblical notion of the world system. The conceptual metaphors THE HEAVEN WORLD IS UP, THE HELL IS DOWN are objectified with the help of the prepositions to and in, that has the meaning of the spatial orientation up / down, respectively. The two worlds, the upper and lower ones, are imagined, but possible from the standpoint of the protagonists who rely on their faith in other worlds. The geometric model of the space in the ballad world corresponds to the monochrome or vector model, that is, it is unfolded in the form of the path of the horizontal or vertical direction (Suvorova, $2015 b$ ), reflecting the model of the real world. The concept HELL is dominant and substitutes all the concepts related to the imagined lower world and is actualized in the ballads through the nominative units devil, hell, down, which initiate the conceptual implicates: physical and mental suffering, death, something bad, unpleasant. In the context of the analyzed ballad text, the concept HELL is characteristic of the image of the husband's wife. It pulls in its conceptual pool of meaning all significant dominant textual concepts actualizing by the metonymy the plague of his life, the conceptual implications: living together is hell for the husband.

\title{
2. OPPORTUNITY TO ACT SUBSTITUTES ACTION.
} An example of this model is found in the system of verbal images in the ballad Things Impossible (\# 160):

\author{
(18) "When carrots grow in meadows green \\ And rivers flow with milk and honey \\ When sugar grows on cherry trees, \\ And men refuse to take hard money, \\ When turtle shells turn diamond rings \\ With pearl and brass, they are compared, \\ When the gold grows on eagle's wings, \\ Fair maids, with you I will be married.
}

The image of the protagonist in the ballad points an imaginative and impossible world based on a model of a real world. All the facts of the invented by the protagonist world are contradictory to what exists in the real world. Thus, the protagonist makes it clear that he has no intention to marry the girl who wants to be married to him. 
The imagined space of the ballad world is formed according to the conceptual scheme THE WORLD IS A CONTAINER OF EVENTS AND OPPORTUNITIES TO ACT. In the ballad work through the verbal image the concept POTENTIAL EFFECTS emerges. The concept tights to the scope of its meaning all other concepts that actualize the impossible world through the nominative units: rivers flow with milk and honey, sugar grows on cherry trees, turtle shells turn diamond rings, gold does Grow on eagle's wings, pearl and brass they are compared. In this way, the concept action is substituted by the concept OPPORTUNITY TO ACT revealing the conceptual implication arising from the context: the inability to marry.

3. POSITIVE / NEGATIVE LIMIT OF SCALE - ENTIRE SCALE. The contextual metonymic shift in the conceptual part of imagery in the ballads demonstrates the axiological dimension of the ballad texts based on the principle of opposition GOOD vs. BAD. So, in the ballad Lady Isabel and the Elf Knight (\# 1), the negative image of the protagonist is given in the first lines through the verbal characteristics of the false knight:

(19) There lived a false knight in London did dwell,

Who courted a lady fair;

And all that he wanted of this pretty maid

Was to take her life away.

The manifested concept BAD replaces the entire scale of values realizing the conceptual implicates: bad, wrong, disorderly, and immoral. All other text concepts, activated by the verbal images of the ballad and realizing the afore-mentioned implications, are charged to the conceptual sphere BAD. The nominative units that objectify the concept BAD in the analyzed ballad, are to take her life away, get part of your father's gold, part of your mother's fee, some strange country, an iron grey, deep water's side, drowned six ladies gay, the seventh one you shall be.

\section{MEGA-CONCEPT}

SUBSTITUTES

TEXTUAL

CONCEPTS. The indicated model of the contextual shift in the structure of the imagery in the folklore ballads is clearly observed in the example from the Ballad «Who Is Tapping at My Bedroom Window?» (\# 24). In the ballad we encounter the following words:

(20) O Mary dear, go and ask your mother

If you my wedded bride might; 
And if she says no, come back and tell me And I'll no longer trouble you.»

The verb ask expresses the meaning of asking for permission, that denotes the deontic modality of permission. That's the way of the art world is formed, it is built due to the polychromous model and with the conceptual metaphor, LIFE IS CYCLE being a basis for it. The attention is drawn to the meaning of somebody's paying respect of parents' viewpoints as parents are the ones who gave life to his beloved hero ballads, and she, in turn, will give birth to the girl the protagonist has fallen in love with.

Thus, the geometry of the space in the ballad world is realized by the conceptual metaphors CONTAINER (THE WORLD IS THE CONTAINER OF EVENTS), the structural metaphors (LIFE IS THE SUBSTANCE), contractual (WORLD IS LAYERED CONSTRUCTION), ontological (WORLD IS LIFE), orientation (WORLD IS VERTICAL AND HORIZONTAL SPACE). Regarding of time models forming the ballad world there are the monochrome, or vector, (LIFE IS WAY TO THE FINAL DESTINATION; THE WORLD IS VERTICAL) and polychrome representations (THE WORLD IS A CIRCLE / CYCLE OF LIFE). All these concepts are replaced by the most abstract textual concept of HUMAN LIFE IN THE WORLD, which is the mega-concept of the whole ballad text.

\section{Conclusions}

In the paper, I described the possible mechanism of the text interpretation via cognitive propositions, amongst which the discursive metonymic model is considered to play the generalizing role, a universal pattern in structuring the abstract textual concepts. The discursive metonymy enhances the comprehension of the ballad world in a shortened form. The discursive metonymy enables the abbreviation of the whole ballad world to the proposition that can be uncovered via the cognitive metaphors that lie in the basis of the ballad images. Multi-method approach allows me to observe the types of the discursive metonymies that unify the concepts of the ballad texts.

As a result, the mechanism of the conceptual metonymy is important for structuring the imagery in the folklore ballads; it is the 
unification of the conceptual structures of different levels of their formation and materialization - the structures that reflect the different stage of the artistic thinking. The complexity of the structure lies in coherence of its elements. It is important for synchronizing their tempo in order to construct a complex organization of ballad images into a system. As a result, the conceptual structures of the ballad texts fall into one tempo, the images start to breathe in the same rhythm.

Thus, the linguistic, cognitive, and verbal features of the ballad genre creation determine the organization of the images in American folklore ballads into a system.

\section{References}

Bart, R. (1989). Izbrannye raboty. Semiotika. Pojetika [Chosen Works. Semiotics. Poetics]. Moscow: Progress [in Russian].

Belousov, K.I. (2005). Tekst: Prostranstvo, Vremja, Temporitm [Text: Space, Time, Temporythm]. Novosybirsk: Sybirsky Ogni [in Russian].

Boldyirev, N.N. (2018). Kontseptualnaya metonimiya na raznyih urovnyah yazyika: Sistema i realizatsiya [Conceptual Metonymy at Different Levels of the Language: System and Implementation]. Tambov: TGU [in Russian].

Boldyirev, N.N. (2000). Kognitivnaya semantika [Cognitive Semantics]. Tambov: TGU [in Russian].

Cienki, A. (2005). Metaphor in the «Strict Father» and «Nurturant Parent» Cognitive Models: Theoretical Issues Raised in an Empirical Study. Cognitive Linguistics, 16 (2), 279-312. https://doi.org/10.1515/cogl.2005.16.2.279

Ferreira, L.C. (2008). A Psycholinguistic Study on Metaphor Comprehension in a Foreign Language. ReVEL, 6 (11), 1-23.

Fodor, J. (1983). The Modularity of Mind. Cambridge. MA: MIT Press. https://doi. org/10.7551/mitpress/4737.001.0001

Gardner, H. (1983). Frames of Mind. New York: Basic Books.

Gardner, E.-E., \& Chickering, G.J. (2004). Ballads and Songs of Southern Michigan. The University of Michigan.

Gibbs, R. (1999). The Poetics of Mind: Figurative Thought, Language, and Understanding. New York: Cambridge University Press.

Ivashina, N., \& Rudenko, E. (2011). Metonimiya: Aspektyi issledovaniya [Metonymy: Aspects of Research]. Linguistica Brunencia [in Russian].

Lakoff, G., \& Johnson, M. (1980). Metaphors We Live by. Chicago: University of Chicago Press.

Lukin, V.A. (1993). Kontsept istinyi i slovo istina v russkom yazyike (Opyit kontseptualnogo analiza ratsionalnogo i irratsionalnogo v yazyike) [The Concept of Truth and the Word Truth in Russian (Experience of Conceptual Analysis of Rational and Irrational in Language)]. Voprosyi yazyikoznaniya - Questions of Linguistics, 4, 63-89 [in Russian].

Moskalchuk, G.G. (2003). Struktura teksta kak sinergeticheskij process [The Structure of the Text as a Synergetic Process]. Moscow [in Russian] 
The Discursive Metonymy in the Imagery of American Folklore...

Niemeier, S. (2003). Applied Cognitive Linguistics and Newer Trends in Foreign Language Teaching Methodology. A. Tyler, M. Takada, Y. Kim \& D. Marinova (Eds.), Cognitive and Discourse Perspectives on Language and Language Learning. Washington: Georgetown University Press.

Pimenova, M.V. (2006). Printsipyi kategorizatsii i kontseptualizatsii mira [Principles of Categorization and Conceptualization of the World]. Yazyik $i$ poznanie: Metodologicheskie problemyi $i$ perspektivyi - Language and Cognition: Methodological Problems and Prospects (pp. 172-186). Moscow: Gnozis [in Russian].

Piñango, M.M., Zhang, M., Foster-Hanson, E., Negishi, M., Lacadie, C., \& Constable, R.T. (2017). Metonymy as Referential Dependency: Psycholinguistic and Neurolinguistic Arguments for a Unified Linguistic Treatment. Cognitive science, 41, 351-378. https://doi.org/10.1111/cogs.12341

Suvorova, T. (2014). The Structure and Organization of a Poetic Creative Entity. In T. Morgan (Chairman), B. Zhytnigor, S. Godvint, et al. (Eds.), Global Trends of Development of Ethnic Languages in the Context of Providing International Communications (pp. 22-25). London: IASHE.

Suvorova, T.M. (2015a). Obraznist amerykanskyx folklornyx balad: kognityvnosemiotychnyj aspekt [Imagery of American Folklore Ballads: Cognitive and Semiotic Aspects]. Naukovyj visnyk Drogobyczkogo derzhavnogo pedagogichnogo universytetu imeni Ivana Franka - Scientific Issue of the Drohobych State Pedagogical University after Ivan Franko, 3, 278-285 [in Ukrainian].

Suvorova, T.M. (2015b). Organizuyucha funkciya obraznosti v amerykanskyh folklornyh baladah [Organizing Function of Imagery in American Folklore Ballads]. Naukovyj visnyk Mizhnarodnogo gumanitarnogo universytetu Scientific Issue of the International Humanitarian University, 15 (2), 144-148 [in Ukrainian].

Truhanovskaya, N.S. (2009). Metonimicheskiy sdvig pri kontseptualizatsii denotativnoy situatsii (v sfere prikladnogo fizicheskogo vozdeystviya) [Metonymic Shift in the Conceptualization of the Denotative Situation (in the Field of Applied Physical Effects)]. Extended abstract of Candidate's thesis. Moscow [in Russian].

Turner, M. (2006) Conceptual Integration and Formal Expression. In M. Turner \& G. Fauconnier (Eds.), Metaphor and Symbolic Activity, 10 (3), 183-204. https:// doi.org/10.1207/s15327868ms1003_3

Yung, K.G. (1992). Dusha i mif: Shest arhetipov [The Soul and Myth: Six Archetypes]. Kyiv: Gos. Biblioteka Ukrainyi dlya yunoshestva [in Russian].

Zhabotynska, S.A. (2010). Principles of Building Conceptual Models for Thesaurus Dictionaries. Cognition, Communication, Discourse, 1, 75-92.

\section{АНОТАЦІЯ}

Вступ. Стаття висвітлює проблему опису семантики американських фольклорних балад з урахуванням зв'язків між образами, задіяними у творення тексту пісень. Дискурсивна метонімія вважається у нашому дослідженні когнітивним механізмом, який облєднує текстові концепти, облєктивовані словесними образами в тканині балад. Завдяки когнітивному механізмові дискурсивної метонімії у процесі творчої реконструккції смислів 
балад відбувається розуміння того, що кожен твір є цілісним облєднанням і репрезентує художню ідею.

Процедура дослідження. Аналіз семантики баладних текстів забезпечується теорією концептуальних тропів взагалі та концептуальної метафори Дж. Лакоффа зокрема. Теорія базових концептів та інтегративних моделей лежать в основі визначення основних моделей дискурсивної метонімії. Реалізація текстової зв'язності відбувається за рахунок лінгвістичних засобів на основі моделей дискурсивної метонімії. До лінгвістичних засобів відносимо повтори на всіх текстових рівнях: фонологічному, лексичному, синтаксичному, що результує у формуванні концептуальних мереж через дискурсивну метонімію на концептуальному рівні.

Результати. Анафора й катафора, еліпсис та кон'юнктиви різного типу також забезпечують текстову зв'язність через механізм дискурсивноі метонімії. Таким чином, механізм дискурсивної метонімії є важливим засобом структурування образності фольклорних балад, оскільки виступає способом об'єднання концептуальних структур, об'єктивованих нарізних рівнях тексту, а також структур, що $\epsilon$ результатом різних періодів розвитку креативного мислення. Комплексність структури образності визначається зв'язністю різнорівневих елементів. Під зв'язністю розуміємо гармонізацію та узгодженість образів баладного твору через дифузні дисипативні процеси.

Висновки. Важливим є те, що синхронізація різних структур образності залежить від розуміння комплексності ma взаємопов'язаності одиниць образності, сприйнятих як системне утворення.

Ключові слова: балада, образ, дискурсивна метонімія, когнітивний механізм, система образів.

Суворова Татьяна. Дискурсивная метонимия в образности американских фольклорных баллад

\section{АННОТАЦИЯ}

Вступление. Статья освещает проблему описания семантики американских фольклорных баллад с учётом связей между образами, которые вовлечены в создание текстов песен. Дискурсивная метонимия считается в нашем исследовании когнитивным механизмом, который объединяет текстовые концепты, объективированные словесными образами в ткани баллад. Благодаря когнитивному механизму дискурсивной метонимии в процессе творческой реконструкции смыслов баллад происходит понимание того, что каждое произведение является целостным объединением образов и репрезентацией художественной идеи.

Процедура исследования. Анализ семантики балладных текстов обеспечивается теорией концептуальных тропов вообще и концептуальной метафоры Дж. Лакофра в частности. Теория базовых моделей и интегративных моделей лежат в основе определения различных моделей дискурсивной метонимии. Реализация текстовой связности осуществляется 
The Discursive Metonymy in the Imagery of American Folklore...

за счёт лингвистических средств на базе дискурсивной метонимии. К лингвистическим средствам связности относим повторы на всех текстовых уровнях: фонологическом, лексическом, синтаксическом, результатом чего является формирование концептуальных сетей через модели дискурсивной метонимии на концептуальном уровне.

Результаты. Анафора, катафора, эллипсис и конъюнкции различного типа также считаются средствами текстовой связности, реализованной через модели дискурсивной метонимии. Таким образом, механизм дискурсивной метонимии выступает важным средством структурирования образности фольклорных баллад, поскольку обеспечивает объединение концептуальных структур, объективированных разными уровнями текста, а также структур, которые сформировались в различные периоды развития креативного мышления. Комплексность структуры образности определяется связностью разноуровневых структур. Под связностью понимаем гармонизацию и согласованность образов балладного произведения через дифрфузные диссипативные процессы.

Выводы. Важным является заключение о том, что синхронизация разных структур образности зависит от понимания комплексности и взаимосвязанности единиц образности, понимаемых как системное образование.

Ключевые слова: баллада, образ, дискурсивная метонимия, когнитивный механизм, система образов. 